\title{
PRODUCTION OF NOVEL ANTIBIOTIC, DOPSISAMINE, BY A NEW SUBSPECIES OF NOCARDIOPSIS MUTABILIS WITH MULTIPLE ANTIBIOTIC RESISTANCE
}

\author{
Atsushi Takahashi, Kunimoto Hotta ${ }^{\dagger}$, Noriko Saito, Moto Morioka, \\ Yoshiro OKAMI and HAMAO UMEZAWA \\ Institute of Microbial Chemistry \\ 3-14-23 Kamiosaki, Shinagawa-ku, Tokyo 141, Japan \\ National Institute of Health, Japan \\ 2-10-35 Kamiosaki, Shinagawa-ku, Tokyo 141, Japan \\ (Received for publication November 9, 1985)
}

\begin{abstract}
An actinomycete isolate designated as TS-1980 with multiple resistance to aminoglycoside antibiotics was found to produce novel antibiotics. The strain showed taxonomic features identical to the type strain of Nocardiopsis mutabilis except for the temperature range for growth and the utilization of mannitol and raffinose. Based on the capability of growing at lower temperature range, the strain was named $N$. mutabilis subsp. cryophilis subsp. nov. Physico-chemical and biological characterization of a purified antibiotic revealed its novel polyamine-type nature with a broad antimicrobial activity. The antibiotic was named dopsisamine.
\end{abstract}

As reported previously ${ }^{1,2)}$, naturally-occurring actinomycete strains with multiple resistance to wide ranges of aminoglycoside (AG) antibiotics show a high probability of antibiotic production. Therefore, the isolation and screening of such actinomycete strains were expected to lead to the discovery of novel antibiotics. A soil actinomycete isolate designated as TS-1980, which produced a mixture of multiple antibiotics, was found to meet the above expectation.

In this report, we describe taxonomic characteristics of the strain TS-1980. Although it should be identified as Nocardiopsis mutabilis ${ }^{3)}$, we observed unique morphologies that were not described in the original report on the taxonomy of the organism. In addition, we describe the physico-chemical and biological properties of one of the antibiotics produced by the strain TS- 1980 as a polyamine-type antibiotic with a broad antimicrobial activity.

\section{Materials and Methods}

Isolation of Organisms

The strain TS-1980 was isolated from a soil collected at Shosenkyo, Yamanashi, Japan. The isolation medium 4PC consisted of the mixture of ISP No. 4 (1 vol) and potato - carrot extract ( 2 vol), $1.5 \%$ agar and $20 \mu \mathrm{g} / \mathrm{ml}$ of two different AG antibiotics (istamycin B and sisomicin). The potato carrot extract consisted of the filtrate of potato $(30 \mathrm{~g})$ and carrot $(2.5 \mathrm{~g})$ boiled in 1 liter of water for 30 minutes.

\section{Taxonomical Examination}

Morphological, cultural and physiological properties of the strain TS-1980 were examined according to the methods described by SHIRLing and GotTLIEB ${ }^{4)}$ and WAKSMAN ${ }^{5)}$. Detailed observation of mycelial morphologies was performed with the use of a light microscope (XF-Ph-21, Nikon), a transmission electron microscope (EM400, Philips) and a scanning electron microscope (Model S700 , Hitachi) after strain TS-1980 was incubated on the various media at $27^{\circ} \mathrm{C}$ for 7 to 14 days. 
Physiological examinations were carried out in terms of carbon utilization on ISP No. 9 medium containing $1.0 \%$ carbon source ${ }^{4)}$, tolerance to 1 to $10 \% \mathrm{NaCl}$ on the ISP No. 4 medium, permissive temperature range for growth on the ISP No. 4 medium by the use of a Temperature Gradient Incubator (Toyo Kagaku Sangyo Co., Japan), and susceptibility to $50 \mu \mathrm{g} / \mathrm{ml}$ of 11 different AG antibiotics $^{1)}$.

Chemical analyses of strain TS-1980 were performed in terms of cell wall type ${ }^{6)}$, whole cell sugar pattern $^{7)}$, cellular phospholipids ${ }^{8)}$, glycolic acid in cell wall ${ }^{9)}$, menaquinones ${ }^{10)}$ and nocardiomycolic $\operatorname{acid}^{11)}$.

The type cultures used for taxonomic comparison were obtained from IFO (Institute for Fermentation, Osaka).

\section{Fermentation}

The medium used for the production of the antibiotics consisted of dextrin $2.0 \%$, glucose $0.2 \%$, soybean meal $2.0 \%, \mathrm{MgSO}_{4} \cdot 7 \mathrm{H}_{2} \mathrm{O} 0.1 \%, \mathrm{NaCl} 0.3 \%$ and $\mathrm{K}_{2} \mathrm{HPO}_{4} 0.1 \%$. A slant culture of the strain TS-1980 on ISP No. 4 medium was inoculated into $100 \mathrm{ml}$ of the medium in a 500-ml vol of Erlenmeyer flask and incubated at $27^{\circ} \mathrm{C}$ for 96 hours on a rotary shaker $(180 \mathrm{rpm})$. One $\mathrm{ml}$ of this culture was then transferred to $100 \mathrm{ml}$ of the fresh medium and incubated for 120 hours in the same way as above. The antibiotic activity of the culture was assayed with Bacillus subtilis PCI 219 as a test organism.

\section{Purification of an Active Substance}

The culture broth (total 15 liters) was filtered at $\mathrm{pH} 2.0$ (adjusted with conc $\mathrm{HCl}$ ) and $\mathrm{pH} 7.0$ (adjusted with $6 \mathrm{~N} \mathrm{NaOH}$ ), successively, by using Hyflo Super-Cel (Johns-Manville Co., USA) as a filter aid. The antibiotic principle in the filtrate (14 liters) was adsorbed on a column of Amberlite IRC-50 $\left(70 \% \mathrm{Na}^{+}, 500 \mathrm{ml}\right)$. After the column was washed with water (5 liters), $1 \mathrm{~N} \mathrm{HCl} \mathrm{(2} \mathrm{liters)} \mathrm{and}$ water (5 liters), successively, the antibiotics were eluted with $0.05 \mathrm{~N} \mathrm{HCl}-80 \%$ aq $\mathrm{MeOH}$ (2 liters). Active fractions were pooled, neutralized with Amberlite IRA-45 $\left(\mathrm{OH}^{-}\right)$, evaporated to $10 \mathrm{ml}$ in vacuo and lyophilized.

The resultant crude yellow powder $(1.89 \mathrm{~g})$ was dissolved in $10 \mathrm{ml}$ of $0.3 \mathrm{M} \mathrm{NaCl}$ solution and charged on a column of CM-Sephadex C-25 which was pre-equilibrated with $0.3 \mathrm{M} \mathrm{NaCl}(500 \mathrm{ml})$. Elution with 5 liters of $\mathrm{NaCl}$ solution with a concentration gradient of $0.3 \mathrm{M}$ to $1.0 \mathrm{M}$ at a flow rate of $100 \mathrm{ml} /$ hour provided roughly three peaks of active fractions (Fig. 1). The active fractions of the peak designated as III were combined and loaded on a column of Amberlite XAD-2 $(50 \mathrm{ml})$. The column was thoroughly washed with deionized water $(1$ liter) and the antibiotics were eluted with $0.05 \mathrm{~N}$ $\mathrm{HCl}-50 \%$ aq acetone. The eluate was neutralized with Amberlite IRA-45 $\left(\mathrm{OH}^{-}\right)$and evaporated to $5 \mathrm{ml}$ in vacuo and lyophilized.

A pale yellow powder of the antibiotics thus obtained $(258 \mathrm{mg})$ was then charged on a column $\left(2 \mathrm{~cm} \times 100 \mathrm{~cm}\right.$ ) of silica gel (Wakogel C-200) and developed with $\mathrm{CHCl}_{3}-\mathrm{MeOH}-\mathrm{NH}_{4} \mathrm{OH}(2: 2: 1)$. The fractionated eluate was monitored with antibiotic activity and silica gel TLC using $\mathrm{CHCl}_{3}$ $\mathrm{MeOH}-\mathrm{AcOH}-\mathrm{H}_{2} \mathrm{O}(3: 1: 1: 0.2)$ as a developing solvent. Fractions showing a blue color spot with anisaldehyde sulfate ( $\operatorname{Rf} 0.32$ ) were pooled and concentrated to dryness. The residue was dissolved in $1 \mathrm{ml}$ of deionized water and passed through a column of Dowex 1-X2 $\left(\mathrm{OH}^{-}\right)$. After adjusting the $\mathrm{pH}$ to 5.0 with $1 \mathrm{~N} \mathrm{H}_{2} \mathrm{SO}_{4}$, the effluent was passed through a column of Dowex 1-X2 $\left(\mathrm{SO}_{4}{ }^{2-}\right)$. The eluate was evaporated to dryness and dissolved in $0.5 \mathrm{ml}$ of $50 \%$ aq $\mathrm{MeOH}$. This aq $\mathrm{MeOH}$ solution containing the antibiotics was passed through a column of Sephadex LH-20 $(2 \mathrm{~cm} \times 100 \mathrm{~cm})$ equilibrated with $50 \%$ aq $\mathrm{MeOH}$ and developed with $50 \%$ aq $\mathrm{MeOH}$. Each fraction $(2 \mathrm{ml})$ was monitored by TLC. The fractions positive to anisaldehyde color reaction were combined and concentrated to $2 \mathrm{ml}$ and lyophilized. Thus, $91.8 \mathrm{mg}$ of white powder of a pure antibiotic exhibiting a single spot by the color reaction with anisaldehyde sulfate on a silica gel TLC plate was obtained.

\section{Determination of Antimicrobial Activity}

To determine the minimal inhibitory concentration of the purified antibiotic, bacteria were incubated at $37^{\circ} \mathrm{C}$ for 18 hours in Mueller-Hinton agar (Difco), and yeasts and molds were incubated at $27^{\circ} \mathrm{C}$ for 18 hours in nutrient agar (Difco) supplemented with $1 \%$ glucose. 
Table 1. Taxonomic features of strain TS-1980.

\begin{tabular}{|c|c|c|}
\hline \multicolumn{3}{|l|}{ Cultural characteristics* } \\
\hline \multirow[t]{2}{*}{ Growth } & Good abundant: & W2, ISP No. $2,4,5$ \& 7 , NA \\
\hline & Moderate: & W1, ISP No. 3 \\
\hline Reverse side color & Pale yellow: & W1 \& 2, ISP No. $2,3,4,5,6 \& 7$, NA \\
\hline \multirow[t]{2}{*}{ Aerial mass color } & White: & W1, ISP No. $2,5 \& 6$, NA \\
\hline & White pale yellow: & W2, ISP No. $3,4 \& 7$ \\
\hline \multicolumn{3}{|l|}{ Morphological characteristics } \\
\hline Substrate mycelium & \multicolumn{2}{|c|}{ “Zig-zag" hyphae: W1, ISP No. 6, NA } \\
\hline \multirow[t]{5}{*}{ Aerial mycerium } & \multicolumn{2}{|c|}{ Long straight hyphae $(\phi 0.2 \sim 0.5 \mu \mathrm{m})$} \\
\hline & \multicolumn{2}{|c|}{ Electron dense particles } \\
\hline & \multicolumn{2}{|l|}{ Segmentation } \\
\hline & \multicolumn{2}{|l|}{ Sporangium-like body } \\
\hline & \multicolumn{2}{|l|}{ Sclerotium-like body } \\
\hline \multicolumn{3}{|l|}{ Chemical characteristics } \\
\hline Cell wall type & \multicolumn{2}{|c|}{ IIIC (meso- and LL-DAP, galactose) } \\
\hline Acyl type & \multicolumn{2}{|l|}{ Acetyl } \\
\hline Phospholipid & \multicolumn{2}{|l|}{ PIV } \\
\hline Menaquinone & \multicolumn{2}{|l|}{ MK9 (H4) } \\
\hline Nocardiomycolic acid & \multicolumn{2}{|l|}{ Negative } \\
\hline Staining & \multicolumn{2}{|c|}{ Gram-positive, non-acid fast, positive to nucleus } \\
\hline \multicolumn{3}{|l|}{ Physiological characteristics } \\
\hline Permissive temperature & \multicolumn{2}{|c|}{$8 \sim 33^{\circ} \mathrm{C}$ (optimal range $21 \sim 27^{\circ} \mathrm{C}$ ) } \\
\hline Carbon utilization Positive: & \multirow{2}{*}{\multicolumn{2}{|c|}{$\begin{array}{l}\text { Glucose, sucrose, xylose, inositol, mannitol, fructose, raffinose } \\
\text { Rhamnose, arabinose (variable) }\end{array}$}} \\
\hline Negative: & & \\
\hline Melanoid pigment & \multicolumn{2}{|c|}{ Negative } \\
\hline Milk coagulation \& peptonization & \multicolumn{2}{|l|}{ Negative } \\
\hline Nitrate reduction & \multicolumn{2}{|l|}{ Positive } \\
\hline Gelatin liquefaction & \multicolumn{2}{|l|}{ Positive } \\
\hline $\mathrm{NaCl}$ tolerance & \multicolumn{2}{|l|}{$1 \sim 3 \%$} \\
\hline
\end{tabular}

* W1; Sucrose - nitrate agar (Waksman No. 1 medium), W2; glucose - asparagine agar (Waksman No. 2 medium), ISP No. 2; yeast - malt extract agar, ISP No. 3; oatmeal agar, ISP No. 4; inorganic salts starch agar, ISP No. 5; glycerol - asparagine agar, ISP No. 6; peptone - yeast extract - iron agar, ISP No. 7; tyrosine agar, NA; nutrient agar.

\section{Results}

Taxonomic Features of the Strain TS-1980

Taxonomic features of the strain TS-1980 were summarized in Table 1. The strain showed good or abundant growth with white to pale yellow aerial mass color on various media. Aerial mycelium consisting of long straight and thin hyphae formed a variety of unique morphological structures. As shown in Photo 1, they divided into long segments (Photo 1-A) which in turn subdivided into short rods with smooth surface (Photo 1-B). Highly electron dense round particles were observed in each segment (Photo 1-A). Hyphae were so adhesive that they developed a bundle or tight loops, resulting in the formation of sporangium- or sclerotium-like structures (Photos 1-C and -D). The substrate mycelium was observed to be "nocardioid"-like zig-zag hyphae. The mycelium grown on agar media was Gram-positive but not acid fast. Nucleus staining revealed the presence of positive particles.

Chemical analyses of cell wall and whole cell sugar revealed other unique aspects of the strain TS-1980. Meso-diaminopimelic acid (DAP) was detected together with lesser amount of LL-DAP in the acid hydrolysate of the purified cell wall preparation. Alanine, glutamic acid and galactose were also detected, but glycine and arabinose were not. Whole cell acid hydrolysate contained galactose, 
Photo 1. Morphology of strain TS-1980.

A, C \& D: ISP No. 4 medium, B: W1 medium, A \& B: a mark equals $1 \mu \mathrm{m}, \mathrm{C} \& \mathrm{D}$ : a mark equals $5 \mu \mathrm{m}$.

A

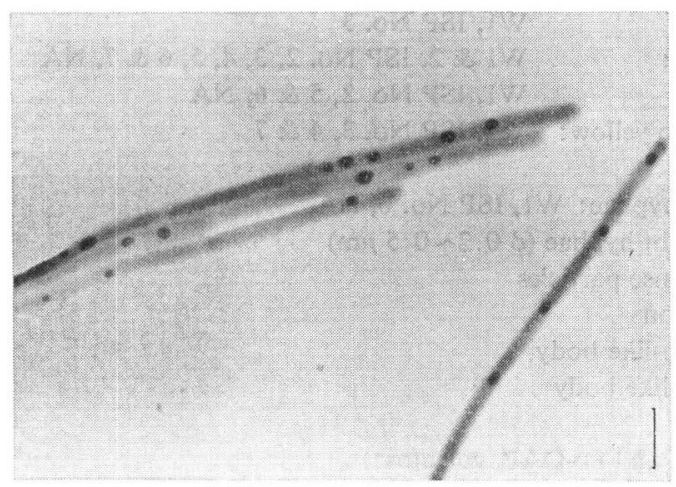

C

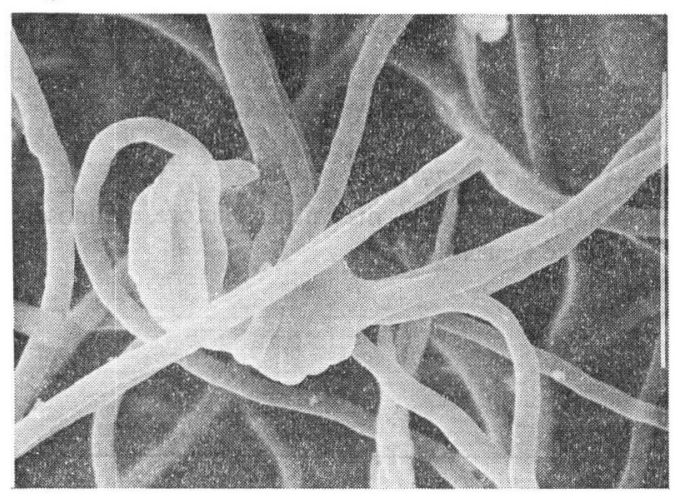

B

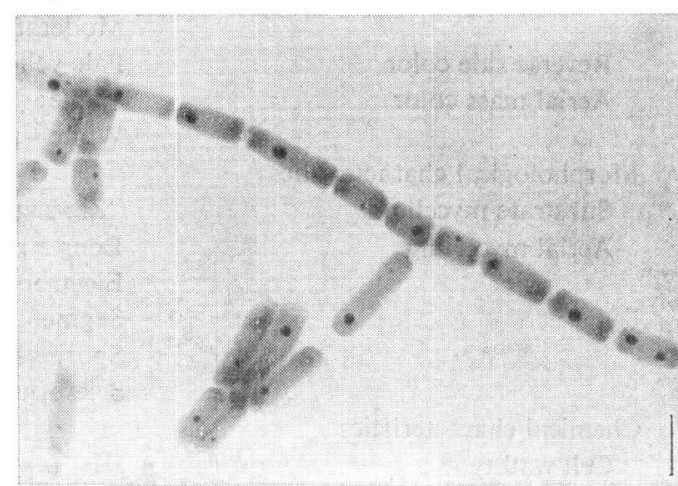

D

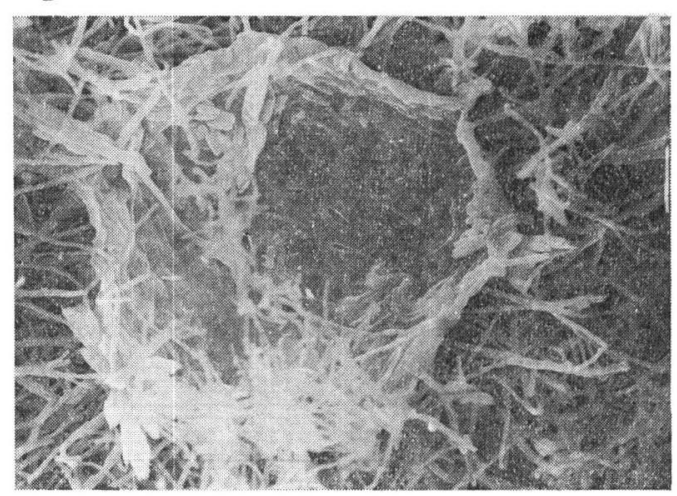

glucose, rhamnose and ribose, but not arabinose, madurose and xylose. These chemical composition of the strain TS-1980 would not allow assignment to any one of the known cell wall types or the known whole cell sugar patterns. However, it would seem to be closely related to type III cell wall and type $\mathrm{C}$ whole cell sugar pattern as in the case of Actinosynnema ${ }^{12)}$. The types of acyl group of cell wall, phospholipids and menaquinone were acetyl, PIV and MK9 (H4), respectively. Nocardiomycolic acid was not detected.

The strain TS-1980 grew at temperature range of $8 \sim 33^{\circ} \mathrm{C}$ with the optimum range of $21 \sim 27^{\circ} \mathrm{C}$. In addition, the strain was resistant to $50 \mu \mathrm{g} / \mathrm{ml}$ of the following $11 \mathrm{AG}$ antibiotics; streptomycin, kanamycin A, dibekacin, gentamicin $\mathrm{C}$, ribostamycin, istamycin B, paromomycin, lividomycin $\mathrm{A}$, butirosin $\mathrm{A}$, neomycin $\mathrm{B}$ and neamine.

Based on the above features, Actinoplanacae and nocardioform actinomycetes ${ }^{13)}$ were chosen as candidate taxa for the strain TS-1980. The comparative examination of type strains belonging to the species of these two taxa together with the strain TS-1980 revealed that N. mutabilis IFO 14310 (ATCC 31520) had the taxonomic features identical to those of the strain TS-1980 with exception of some physiological difference. The type strain (IFO 14310) of N. mutabilis grew at the range of $15 \sim$ $42^{\circ} \mathrm{C}$, whereas the strain TS- 1980 at $8 \sim 33^{\circ} \mathrm{C}$. The type strain did not utilize mannitol and raffinose as sole carbon sources and was sensitive to kanamycin A, while the strain TS-1980 gave the opposite results in these respects. Thus, the most significant and distinct difference lay in the permissive tem- 
Fig. 1. CM-Sephadex C-25 column chromatography.

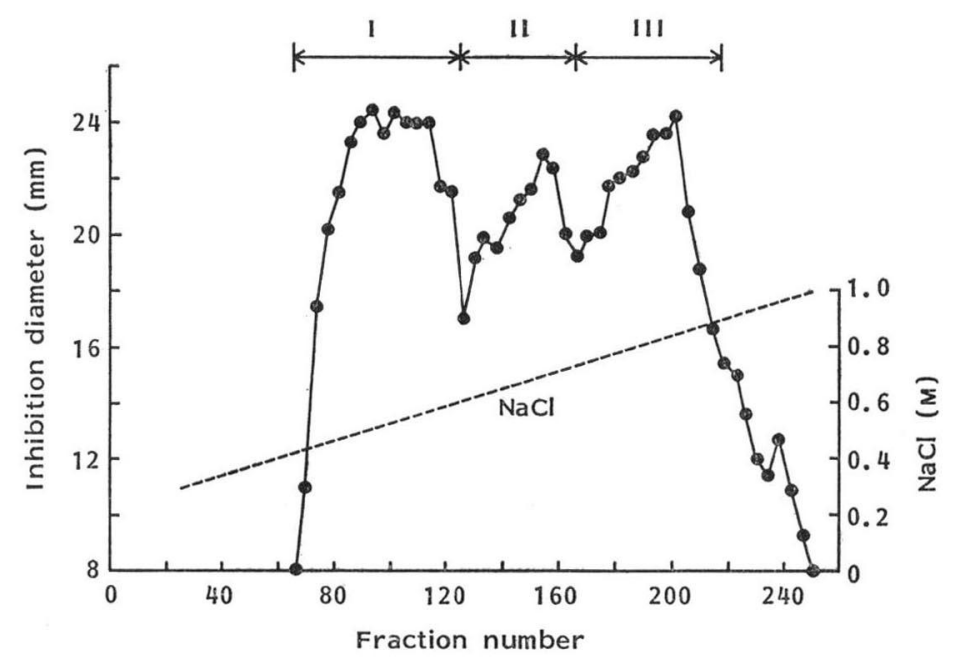

perature for growth. The strain TS-1980 was therefore classified as a new subspecies of N. mutabilis. N. mutabilis subsp. cryophilis subsp. nov. Takahashi, Hotta et Okami was the designation given to the strain TS-1980 which was nominated as the type and deposited at IFO. It should be noted that N. mutabilis IFO 14310 exhibited the same unique morphological structures as those observed in the strain TS-1980, because these morphologies were not described in the original report on the type strain ${ }^{3)}$.

\section{Physico-chemical Properties of the Antibiotic}

The strain TS-1980 produced a mixture of antibiotic substances with similar physico-chemical properties. As shown in Fig. 1, at least three peaks appeared in the antibiotic activity curve after CM-Sephadex C-25 chromatography. In the course of the purification, each peak was found to contain several antibiotic substances (data not shown). Thus, at least 20 antibiotics were contained in the filtrate of the culture broth. One of the antibiotics in the peak designated as III in Fig. 1 was purified as described in Materials and Methods, and named dopsisamine.

Physico-chemical properties of dopsisamine were summarized in Table 2. The antibiotic is a hygroscopic white powder which is water soluble and basic, and positive to Sakaguchi and anisaldehyde sulfate color reactions. The IR spectrum was shown in Fig. 2. The UV absorption spectrum showed two major peaks at 206 and $305 \mathrm{~nm}$ in phosphate buffer (pH 6.8). In $0.1 \mathrm{~N} \mathrm{HCl}$, the peak at $305 \mathrm{~nm}$ shifted to $322 \mathrm{~nm}$. Elemental analysis and the spectra of FD-MS, SI-MS, ${ }^{1} \mathrm{H}$ NMR and ${ }^{13} \mathrm{C}$ NMR established the molecular formula of $\mathrm{C}_{30} \mathrm{H}_{55} \mathrm{~N}_{11} \mathrm{O}_{3} \cdot 3 / 2 \mathrm{H}_{2} \mathrm{SO}_{4} \cdot \mathrm{H}_{2} \mathrm{O}$. The ${ }^{1} \mathrm{H}$ NMR (in $\mathrm{D}_{2} \mathrm{O}, 400 \mathrm{MHz}$ ) spectrum (Fig. 3) indicated the presence of one olefinic proton (5.16 ppm), two methyl groups (1.67 and $1.71 \mathrm{ppm})$ and one methoxy group $(3.95 \mathrm{ppm})$. Furthermore, decoupling analysis indicated the possible presence of two kinds of carbon chain linked to the nitrogen atom, $2 \times\left(\mathrm{NCH}_{2} \mathrm{CH}_{2} \mathrm{CH}_{2} \mathrm{~N}\right)$ and $2 \times\left(\mathrm{NCH}_{2} \mathrm{CH}_{2} \mathrm{CH}_{2} \mathrm{C}\right)$, and tri-substituted olefin, $\left(\mathrm{CH}_{3}\right)_{2} \mathrm{C}=\mathrm{C}_{-}^{\prime} \mathrm{CH}_{2}{ }^{-}$. The reaction of dopsisamine with acetylacetone in water in the presence of potassium carbonate gave bis(dimethylpyrimidyl) derivative $(\mathrm{m} / \mathrm{z} 745$ and 746 in EI-MS and SI-MS, respectively), indicating the probable existence of guanidino carbons which could correspond to two out of three signals at 157.9, 157.4 and $157.1 \mathrm{ppm}$ in the chemical shift data of the ${ }^{13} \mathrm{C}$ NMR spectrum (Table 3). These physico-chemical properties 
Table 2. Physico-chemical properties of dopsisamine sulfate.

\begin{tabular}{|c|c|}
\hline Appearance & White powder \\
\hline Melting point & $155 \sim 160^{\circ} \mathrm{C}$ \\
\hline \multicolumn{2}{|l|}{$\mathrm{UV} \max \left(\mathrm{E}_{1 \mathrm{~cm}}^{1 \%}\right) \mathrm{nm}$} \\
\hline Phosphate buffer (pH 6.8) & 206 (183), 220 (sh, 142), 280 (sh, 53), 305 (126) \\
\hline $0.1 \mathrm{~N} \mathrm{HCl}$ & 206 (183), 235 (149), 322 (168) \\
\hline $0.1 \mathrm{~N} \mathrm{NaOH}$ & 216 (212), 280 (sh, 53), 306 (129) \\
\hline Molecular weight FD-MS $(\mathrm{M}+\mathrm{H})^{+}$ & 618 \\
\hline SI-MS $(\mathrm{M}+\mathrm{Na})^{+}$ & 640 \\
\hline Molecular formula & $\mathrm{C}_{30} \mathrm{H}_{55} \mathrm{~N}_{11} \mathrm{O}_{3} \cdot 3 / 2 \mathrm{H}_{2} \mathrm{SO}_{4} \cdot \mathrm{H}_{2} \mathrm{O}$ \\
\hline Elemental analysis Found: & C 46.22, H 8.38, N 19.07, S 6.09 \\
\hline Calcd: & C 46.04, H 7.67, N 19.69, S 6.14 \\
\hline Solubility Soluble: & $\mathrm{H}_{2} \mathrm{O}$ \\
\hline Insoluble: & $\begin{array}{l}\mathrm{MeOH} \text { (emulsion), EtOH (emulsion), } \mathrm{BuOH} \text {, acetone, } \\
\text { EtOAc, } \mathrm{CHCl}_{3} \text {, benzene }\end{array}$ \\
\hline $\begin{aligned} \text { Color reaction Positive: } \\
\text { Negative: }\end{aligned}$ & $\begin{array}{l}\text { Sakaguchi, anisaldehyde }-\mathrm{H}_{2} \mathrm{SO}_{4} \\
\text { Ninhydrin, aniline phthalate }\end{array}$ \\
\hline Rf values on silica gel TLC & $\begin{array}{l}0.32\left(\mathrm{CHCl}_{3}-\mathrm{MeOH}-\mathrm{AcOH}-\mathrm{H}_{2} \mathrm{O}, 3: 1: 1: 0.2\right) \\
0.46\left(\mathrm{BuOH}-\mathrm{AcOH}-\mathrm{H}_{2} \mathrm{O}, 3: 1: 1\right)\end{array}$ \\
\hline $\begin{array}{l}\text { High voltage paper } \\
\text { electrophoresis }(3,000 \text { Volt })\end{array}$ & $\mathrm{Rm} 1.34$ (Ala 1.00) \\
\hline
\end{tabular}

Fig. 2. IR spectrum of dopsisamine sulfate (KBr).

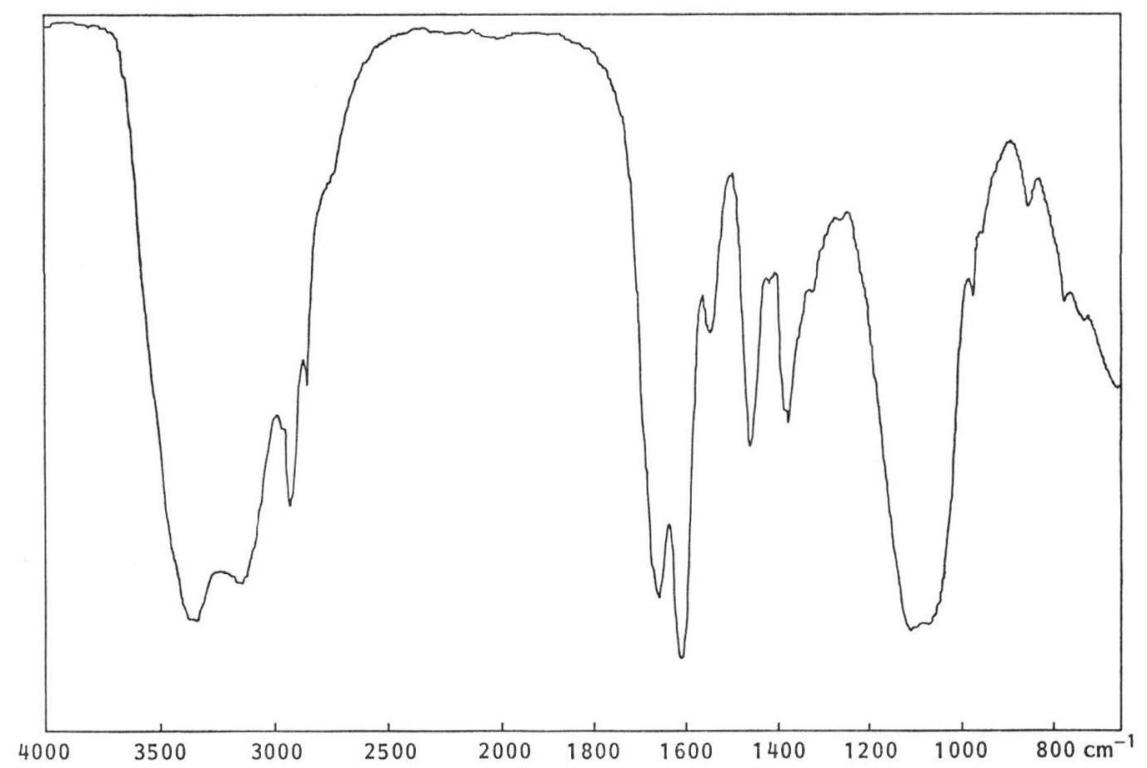

indicate that dopsisamine is a new polyamine-type antibiotic different from any known antibiotic ever reported.

\section{Biological Activities of Dopsisamine}

Table 4 shows MIC of dopsisamine against bacteria, yeasts and molds. It was active to Grampositive and Gram-negative bacteria except Serratia and Pseudomonas. A high activity was also observed in Saccharomyces cerevisiae and weak activity to Xanthomonas oryzae, Candida albicans and molds. Acute toxicity $\left(\mathrm{LD}_{50}\right.$, iv) in mice was about $0.6 \mathrm{mg} / \mathrm{kg}$. 
Fig. 3. ${ }^{1} \mathrm{H}$ NMR spectrum of dopsisamine sulfate $\left(400 \mathrm{MHz}, \mathrm{D}_{2} \mathrm{O}\right)$.

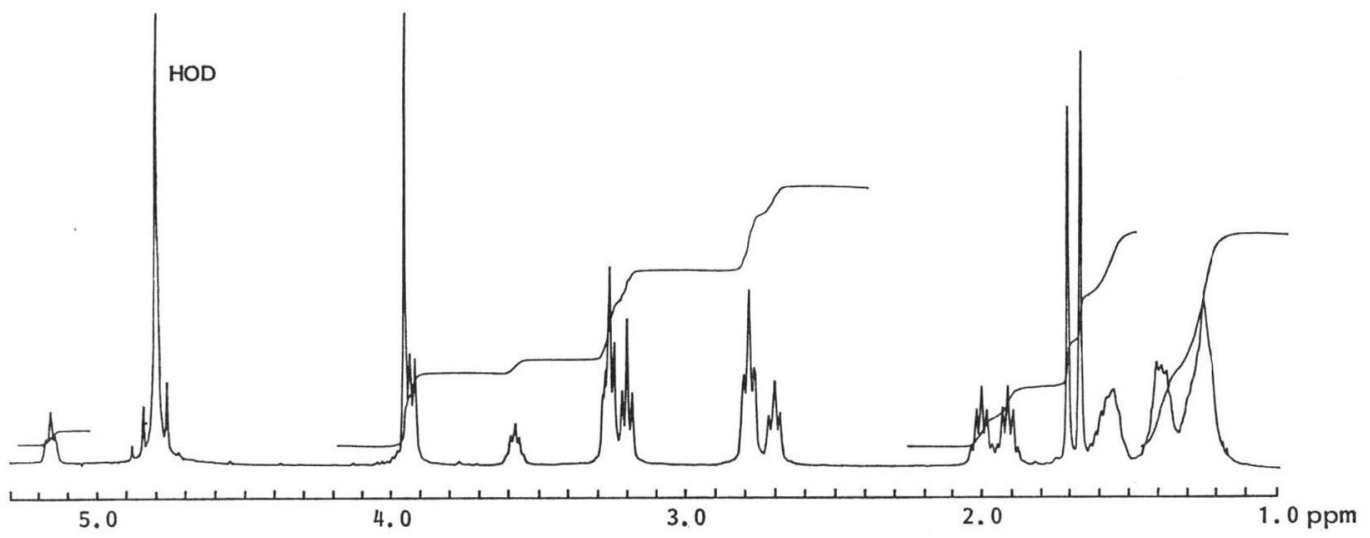

Table 3. Chemical shifts of carbon in the ${ }^{13} \mathrm{C}$ NMR $\left(100.4 \mathrm{MHz}, \mathrm{D}_{2} \mathrm{O}\right)$ spectrum of dopsisamine.

\begin{tabular}{ccc}
\hline $\begin{array}{c}\text { Carbon } \\
\text { number }\end{array}$ & $\begin{array}{c}\text { Chemical } \\
\text { shift }(\delta)\end{array}$ & $\begin{array}{c}\text { Multi- } \\
\text { plicity* }\end{array}$ \\
\hline 1 & 157.9 & $\mathrm{~s}$ \\
2 & 157.4 & $\mathrm{~s}$ \\
3 & 157.1 & $\mathrm{~s}$ \\
4 & 149.3 & $\mathrm{~s}$ \\
5 & 146.7 & $\mathrm{~s}$ \\
6 & 143.6 & $\mathrm{~s}$ \\
7 & 139.9 & $\mathrm{~s}$ \\
8 & 118.1 & $\mathrm{~d}$ \\
9 & 72.1 & $\mathrm{~d}$ \\
10 & 54.8 & $\mathrm{q}$ \\
11 & 49.3 & $\mathrm{t}$ \\
12 & 47.8 & $\mathrm{t}$ \\
13 & 41.7 & $\mathrm{t}$ \\
14 & 41.6 & $\mathrm{t}$ \\
15 & 37.0 & $\mathrm{t}$ \\
16 & 36.5 & $\mathrm{t}$ \\
17 & 33.2 & $\mathrm{t}$ \\
18 & 30.6 & $\mathrm{t}$ \\
19 & 30.2 & $\mathrm{t}$ \\
20 & 29.7 & $\mathrm{t}$ \\
21 & 29.6 & $\mathrm{t}$ \\
22 & 29.3 & $\mathrm{t}$ \\
23 & 29.2 & $\mathrm{t}$ \\
24 & 28.1 & $\mathrm{t}$ \\
25 & 27.7 & $\mathrm{t}$ \\
26 & 27.5 & $\mathrm{t}$ \\
27 & 25.9 & $\mathrm{q}$ \\
28 & 25.6 & $\mathrm{t}$ \\
29 & 23.0 & $\mathrm{t}$ \\
30 & 18.2 & $\mathrm{q}$ \\
\hline
\end{tabular}

* $\mathrm{q}=$ Quartet, $\mathrm{t}=$ triplet, $\mathrm{d}=$ doublet, $\mathrm{s}=$ singlet.
Table 4. Antimicrobial activity of dopsisamine.

\begin{tabular}{lc}
\hline \multicolumn{1}{c}{ Organisms } & $\begin{array}{c}\mathrm{MIC} \\
(\mu \mathrm{g} / \mathrm{ml})\end{array}$ \\
\hline Staphylococcus aureus 209P & 0.39 \\
Micrococcus luteus IFO 3333 & 0.78 \\
Bacillus subtilis PCI 219 & 6.25 \\
Escherichia coli $\mathrm{NIHJ}$ & 3.12 \\
Proteus vulgaris OX19 & 6.25 \\
Serratia marcescens & 100 \\
Klebsiella pneumoniae PCI 602 & 6.25 \\
Mycobacterium smegmatis ATCC 607 & $3.12^{*}$ \\
Pseudomonas aeruginosa No. 12 & 100 \\
Candida albicans 3147 & 25 \\
Saccharomyces cerevisiae F-7 & 3.12 \\
Pyricularia oryzae P-2 & 50 \\
Xanthomonas oryzae & 25 \\
Aspergillus niger F-16 & 50 \\
Trichophyton mentagrophytes (833) & 50 \\
\hline * 37 ${ }^{\circ}$ C, 40 hours. & \\
&
\end{tabular}

\section{Discussion}

Our first step of screening program for new antibiotics has been directed to select actinomycete isolates or clones with multiple resistance to $A G$ antibiotics and/or unique $A G$ antibiotics resistance pattern. This strategy was established on the basis of our findings ${ }^{1,2)}$ that actinomycete strains with multiple AG antibiotic resistance exhibit very high probability of antibiotic production, and that unique resistance patterns correlate strongly with the types of antibiotics produced. This approach resulted in the discovery of indolizomycin by selecting a clone with a unique multiple AG antibiotic resistance pattern after a fusion treatment between Streptomyces strains belonging to two different species ${ }^{14 \sim 16)}$. In the present paper, a new polyamine-type antibiotic was discovered by selecting a novel actinomycete 
isolate with multiple AG antibiotic resistance. Although the strain TS-1980 was identified as $N$. mutabilis, the antibiotic produced was different from polynitroxin ${ }^{17)}$ produced by the type strain of N. mutabilis. The type strain is sensitive to kanamycin A to which the strain TS-1980 is resistant, although both strains are resistant to the other $10 \mathrm{AG}$ antibiotics tested. Therefore, our hypothesis that a strain-specific resistance-pattern may represent strain specificity of antibiotic synthesis was again supported. Recently, resistance genes and the biosynthetic genes for the same antibiotics were reported to be located in the same cluster ${ }^{18,19)}$. Therefore, our approach might be rationalized for the discovery of new antibiotics.

The strain TS-1980 exhibited taxonomic features identical with those of $N$. mutabilis IFO 14310. However, we observed distinct morphological features which were not described in speciation of $N$. mutabilis Shearer $^{3)}$. The sclerotium- or sporangium-like bodies were not described as major morphological characteristics of Nocardiopsis. Whole cell of $N$. mutabilis including the strain TS-1980 contained menaquinone MK9 (H4), phospholipid PIV and galactose, while that of type species of Nocardiopsis, N. dassonvillei contained MK10, phospholipid PIII and no galactose. In addition, N. mutabilis markedly differs from the other species of Nocardiopsis in respect to resistance to AG antibiotics. All type strains of species in Nocardiopsis except $N$. mutabilis were sensitive to 11 AG antibiotics tested, while $N$. mutabilis IFO 14310 and TS-1980 were resistant to 10 and 11 AG antibiotics, respectively. These facts indicate that $N$. mutabilis might need an appropriate taxonomic niche different from the other species of Nocardiopsis.

Acknowledgments

We are grateful to Dr. S. NAKAZAWA, National Institute of Health, Japan, for scanning electron microscopy and Dr. T. OKAZAKI, Sankyo Co., Ltd. for valuable comments for classification of the strain TS-1980.

\section{References}

1) Hotta, K.; A. Takahashi, N. Saito, Y. OKami \& H. UmeZawa: Multiple resistance to aminoglycoside antibiotics in actinomycetes. J. Antibiotics 36: 1748 1754, 1983

2) Hotta, K.; A. Takahashi, Y. OKami \& H. Umezawa: Relationship between antibiotic resistance and antibiotic productivity in actinomycetes which produce aminoglycoside antibiotics. J. Antibiotics 36: 1789 1791, 1983

3) Shearer, M. C.; P. M. Colman \& C. H. NASh, III: Nocardiopsis mutabilis, a new species of nocardioform bacteria isolated from soil. Int. J. Syst. Bacteriol. 33: 369 374, 1983

4) Shirling, E. D. \& D. Gotrlieb: Methods for characterization of Streptomyces species. Int. J. Syst. Bacteriol. 16: 313 340, 1966

5) Waksman, S. A.: The Actinomycetes. Vol. II. The Wilkins Company, Baltimore, 1961

6) Becker, B.; M. P. Lechevalier \& H. A. Lechevalier: Chemical composition of cell wall preparation from strains various form genera of aerobic actinomycetes. Appl. Microbiol. 12: 236 243, 1965

7) Lechevalier, M. P. \& H. A. Lechevalier: Chemical composition as a criterion in the classification of aerobic actinomycetes. Int. J. Syst. Bacteriol. 20: 435 443, 1970

8) Lechevalier, M. P. \& H. A. Lechevalier: The Chemotaxonomy of Actinomycetes. Society for Industrial Microbiology. Arlington, Virginia, 1980

9) UCHIDA, K. \& K. AIDA: Acyltype of bacterial cell wall; its simple identification by colorimetric method. J. Gen. Appl. Microbiol. 23: 249 260, 1977

10) Collins, M. D.; T. Prrous \& M. Goodfellow: Distribution of menaquinones in actinomycetes and corynebacteria. J. Gen. Microbiol. 100: $221 \sim 230,1977$

11) Mordarska, H.; M. Mordarski \& M. Goodfellow: Chemotaxonomic characters and classification of some nocardioform bacteria. J. Gen. Microbiol. 71: 77 86, 1972

12) Hasegawa, T.; M. P. Lechevalier \& H. A. Lechevalier: New genus of the Actinomycetales: Actinosynnemma gen. nov. Int. J. Syst. Bacteriol. 28: 304 310, 1978

13) PRAUSER, H.: New nocardioform organisms and their relationship. In Actinomycetes: The Boundary Microorganisms. Ed., T. ARAI, pp. 193 207, University Park Press, Baltimore, 1976

14) Gomi, S.; D. Ikeda, H. Nakamura, H. Naganawa, F. Yamashita, K. Hotta, S. Kondo, Y. Okami, H. UMEZAWA \& Y. IITAKA: Isolation and structure of a new antibiotic, indolizomycin, produced by a strain SK2-52 obtained by interspecies fusion treatment. J. Antibiotics 37: 1491 1494, 1984 
15) Yamashita, F.; K. Hotta, S. Kurasawa, Y. Okami \& H. Umezawa: New antibiotic-producing streptomycetes, selected by antibiotic resistance as a marker. I. New antibiotic production generated by protoplast fusion treatment between Streptomyces griseus and S. tenjimariensis. J. Antibiotics 38: 58 63, 1985

16) HotтA, K.; F. Yamashita, Y. OKAmi \& H. Umezawa: New antibiotic-producing streptomycetes, selected by antibiotic resistance as a marker. II. Features of a new antibiotic-producing clone obtained after fusion treatment. J. Antibiotics 38: 64 69, 1985

17) Jain, T. C.; D. J. Newman \& M. C. Shearer (Smith Kline \& Co.): Polynitroxin antibiotics produced by Nocardiopsis mutabilis Shearer sp. nov. ATCC31520. U.S. Patent 4,317,812, Mar. 2, 1982

18) Ohnuki, T.; T. Imanaka \& S. Aiba: Self-cloning in Streptomyces griseus of an str gene cluster for streptomycin biosynthesis and streptomycin resistance. J. Bacteriol. 164: 85 94, 1985

19) Baltz, E. H.; P. Matsushima, R. Stanzak, B. E. Schoner \& R. N. Rao: Efficient transformation and cloning of macrolide antibiotic gene in Streptomyces. 6th International Symposium on the Biology of Actinomycetes. Abstract No. L6, Hungary, 1985 